\title{
Titanium dioxide nanoparticles alleviate cadmium toxicity in lentil (Lens culinaris Medic) seeds
}

\author{
Hassan FEIZI ${ }^{1,2}$, Nafiseh AGHELI ${ }^{1}$, Hossein SAHABI ${ }^{1}$
}

Titanium dioxide nanoparticles alleviate cadmium toxicity in lentil (Lens culinaris Medic) seeds

Abstract: This research was carried out with the aim of investigating the effects of different concentrations of titanium dioxide nanoparticles and cadmium on lentil seed germination and seedling early growth. The experiment was conducted as a factorial layout based on a completely randomized design with four replicates. Test plants were exposed to 0, 100, 250, and $500 \mathrm{ppm}$ of cadmium, and then amended with 0, 100, 200, and $300 \mathrm{ppm}$ of $\mathrm{TiO}_{2}$ nanoparticles. Results demonstrated that the application of $300 \mathrm{ppm}$ of titanium dioxide nanoparticles improved the mean germination time (MGT) and seed germination rate by $39 \%$ and $62 \%$ respectively. Most traits exhibited a decreasing trend as the concentration of cadmium increased. Furthermore, application of 500 ppm of cadmium concentration increased mean germination time compared to the control group (1.667 day). In conclusion, the application of titanium dioxide nanoparticles averted the effect of high cadmium stress on lentils, and maintained the length of the shoot compared to the control. However, further studies on plant life cycles should be performed to detect the inhibitory effects of titanium dioxide on heavy metal toxicity.

Key words: heavy metals; cadmium; germination; nanoparticles
Received April 11, 2019; accepted May 29, 2020.

Delo je prispelo 11. aprila 2019, sprejeto 29. maja 2020.
Nanodelci titanovega dioksida zmanjšujejo strupenost kadmija pri kalečih semenih leče (Lens culinaris Medic)

Izvleček: Namen raziskave je bil preučiti učinke različnih koncentracij nanodelcev titanovega dioksida in kadmija na kalitev semen leče in zgodnjo rast njenih sejank. Poskus je bil izveden kot popolni naključni faktorski poskus s štirimi ponovitvami. Testirane rastline so bile izpostavljene $0,100,250$ in 500 ppm kadmija, s kasnejšim dodatkom 0, 100, 200 in 300 ppm nanodelcev $\mathrm{TiO}_{2}$. Rezultati so pokazali, da je dodatek 300 ppm nanodelcev titanovega dioksida izboljšal poprečni čas kalitve (MGT) za $39 \%$ in hitrost kalitve za $62 \%$. Večina merjenih znakov je pokazala padajoč trend s povečevanjem koncentracije kadmija. Uporaba 500 ppm koncentracije kadmija je povečala poprečni čas kalitve za 1,667 dni v primerjavi s kontrolo. Zaključimo lahko, da je pri leči uporaba nanodelcev titanovega dioksida odpravila učinke stresa velikih koncentracij kadmija in ohranila dolžino poganjkov primerljivo s kontrolo. Vsekakor pa so potrebne še nadaljne raziskave življenskega kroga rastlin za ugotavljanje inhibitornih učinkov titanovega dioksida na toksičnost težkih kovin.

Ključne besede: težke kovine; kadmij; kalitev; nanodelci

1 University of Torbat Heydarieh, Department of Plant Production, Torbat Heydarieh, Iran

2 Corresponding author, e-mail: h.feizi@torbath.ac.ir 


\section{INTRODUCTION}

Nowadays, the need for agricultural production, along with the demand for plant raw materials for food production, has increased in the world. In this condition, the use of some branches of the industry in new research and the adoption of safe decisions are necessary to increase agricultural production. Anthropogenic activity degrades the soil, water, and atmosphere and this has led to the search for sustainable ways to improve food production (Feizi \& Rezvani Moghadam, 2010).

Soil contamination with heavy metals is one of the most important environmental problems worldwide. Upon gaining entry into agricultural lands, heavy metals can be absorbed by plants and transferred to humans through the food chain. The increase in the heavy metal content in the human body is due to the consumption of plant products grown in areas contaminated with these metals, inhaling soil particles and consuming contaminated water (Motesharezadeh et al., 2014). Among heavy metals, cadmium is one of the most toxic elements which has no biological role in humans. Cadmium $(\mathrm{Cd})$ is an unnecessary element with high biological durability causing tubalization of leaves, chlorosis and reduced root and stem growth (Ahmadvand et al., 2012). In plants, $\mathrm{Cd}$ exposure frequently triggers negative effects on their growth and productivity. Recently, it has been proved that $\mathrm{Cd}$ can also increase root length and number, and consequently, root area and volume. In plant shoots, Cd can improve the content of photosynthetic pigments and enzymatic and non-enzymatic antioxidants are enhanced in both roots and shoots (Carvalhoa, et al. 2020).

Although plants need some heavy metals such as zinc, iron, nickel, titanium etc. at very low concentrations, however, it leads to metabolic disorders and inhibitory growth of most plant species when the concentration of these metals is higher than the plant requirement. Recently, scientists and researchers have begun to develop efficient and inexpensive technologies, such as the use of microorganisms and living plants to remediate contaminated areas. (Ahmadvand et al., 2012).

Titanium is one of the beneficial elements for plant, and can stimulate the absorption of other elements such as nitrogen, phosphorus, calcium, magnesium, iron, manganese and zinc (Pais, 1983). $\mathrm{TiO}_{2}$ nanoparticles have shown considerable advantages in absorbing and concentrating chemical pollutants owing to their exclusive properties such as high surface area-to-volume ratio, enhanced surface activity, and high affinity (Deng et al., 2017). In one study on fennel plants, it was observed that treatment with $60 \mathrm{ppm}$ titanium dioxide nanoparticles significantly improved the seed germination percentage and germination rate (Feizi et al., 2013). In addition, the highest mean activity of ascorbate peroxidase, guaiacol peroxidase, and catalase enzymes on annual medic plant (Medicago scutellata L.) was found in foliar application of titanium nanoparticles in $0.06 \%$ concentration (Dolatabadi et al., 2015).

Previous studies indicated that $\mathrm{TiO}_{2}$ nanoparticles had high efficiency and adsorption rate for $\mathrm{Pb}, \mathrm{Cd}, \mathrm{Cu}$, $\mathrm{Zn}$, and $\mathrm{Ni}$ (Engates \& Shipley, 2011). The potential influence of $\mathrm{TiO}_{2}$ nanoparticles on the uptake and toxicity of heavy metals in biological systems has been documented. $\mathrm{TiO}_{2}$ nanoparticles significantly enhanced the bioaccumulation and toxicity of $\mathrm{Pb}, \mathrm{Cu}, \mathrm{As}(\mathrm{III}), \mathrm{Zn}$, and $\mathrm{Cd}$ in zebra fish (Danio rerio Haмilton, 1882) larvae, Daphnia magna Straus, 1820, and carp (Cyprinus carpio Linnaeus, 1758) (Miao et al., 2015; Tan \& Wang, 2014). However, Chen et al. (2015) reported that the bioavailability and toxicity of $\mathrm{Cd}$ and $\mathrm{Cu}$ are reduced in alga (Chlamydomonas reinhardtii P.A.Dang) and (Microcystis aeruginosa Kützing ) and amphipod (Gammarus fossarum Linnaeus, 1758) by simultaneous exposure to $\mathrm{TiO}_{2}$ nanoparticles. Although both stimulatory and inhibitory impacts of nanoparticles on various crop species have been reported in the literature, there is limited information on the impact of $\mathrm{TiO}_{2}$ nanoparticles in heavy metal stress.

This work investigated the impact of $\mathrm{TiO}_{2}$ nanoparticles in ameliorating the hazardous effects of Cd on seed germination and seedling growth of lentil. Furthermore, it assesses the co-effect of $\mathrm{TiO}_{2}$ nanoparticles and cadmium on lentil seedling. Therefore, our objectives were to (i) survey Cd-stressed lentil seed germination parameters using $\mathrm{TiO}_{2}$ nanoparticles, (ii) evaluate inhibitory effects of cadmium on lentil seedling and (iii) evaluate protective role of $\mathrm{TiO}_{2}$ nanoparticles under cadmium toxicity conditions.

\section{MATERIALS AND METHODS}

This research was carried out in the laboratory of Medicinal plants of Faculty of Agriculture, University of Torbat Heydarieh, Iran with the aim of investigating the co-effects of different concentrations of titanium dioxide nanoparticles and cadmium sulfate on lentil seed of Gachsaran cultivar (based on literature minimum concentration of $\mathrm{Cd}$ that could harm the lentil is unknown). This experiment was conducted as a factorial based on a completely randomized design with four replicates (in total 1600 seeds). We had a total 16 treatment combinations. We had four replicate for 16 treatments and considered 25 seeds in each treatment $(25$ seeds into each Petri dish). Consequently we calculated $4 \times 4 \times 4 \times 25$ $=1600$ seeds. The first factor consisted of different levels of cadmium sulfate concentration of $0,100,250$ and 500 


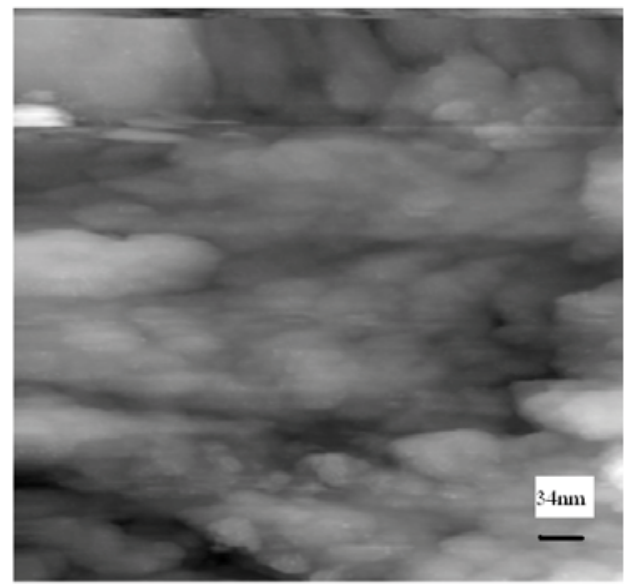

Figure 1: Image of nanosized $\mathrm{TiO}_{2}$ by Scanning Tunneling Microscope (STM)

ppm, and the second factor included the concentrations of $\mathrm{TiO}_{2}$ nanoparticles of $0,100,200$ and $300 \mathrm{ppm}$. Cadmium sulfate $\left(\mathrm{CdSO}_{4}\right)$ as a salt of cadmium was used for preparing cadmium stress treatment. First, healthy lentil seeds were selected and disinfected with sodium hypochlorite $5 \%$ for 60 seconds, then washed with distilled water three times.

The titanium dioxide nanoparticle powder was AEROXIDE $\mathrm{TiO}_{2}$ P25 prepared from Evonik Degussa GmbH Company of Germany. The purity of nanoparticle powder was $99.8 \%$ and the mean particle size was $21 \mathrm{~nm}$. The required amount for each treatment level of titanium dioxide was weighted using a digital scale with a precision of $0.0001 \mathrm{~g}$ and by adding distilled water as the suspension. In order to obtain properly dispersed and stable $\mathrm{TiO}_{2}$ suspensions of each concentration, an ultra-sonication treatment was applied to nanoparticles $\mathrm{TiO}_{2}$ powders dispersed in water for $15 \mathrm{~min}$. After preparation, the nanoparticles were poured in different concentrations at separate Erlenmeyer flasks and the seeds were soaked in each concentration for 2 hours. The Erlenmeyer flasks were placed on a shaker to prevent the deposition of nanoparticles, so that the seeds had an identical contact surface with nanoparticles during the treatment. The size of $\mathrm{TiO}_{2}$ nanoparticles (Figure 1) were determined by Scanning Tunneling Microscope (STM) in Central Laboratory of Ferdowsi University of Mashhad, Iran.

Then, they were placed in a 25 -seed group with an appropriate distance from each other in each Petri dish. The experimental unit consisted of a sterile Petri dish with a culture medium of filter paper type (TP or paper culture method). Filter paper was packed in a double layer of aluminum foil for disinfection and placed in oven for 2 hours at a temperature of $120^{\circ} \mathrm{C}$, then, $5 \mathrm{ml}$ of cadmium sulfate solution was added to each Petri dish. Distilled water was used for control treatment. Petri dishes were placed inside the germinator at $23 \pm 1^{\circ} \mathrm{C}$ at $16 / 8$ hours length in day / night (ISTA, 2009). The daily count of germinated seeds was performed every 12 hours in each experimental unit and seeds with seminal root length of more than two millimeters were counted as germinated seeds (ISTA, 2009). After a period of time necessary for planting seeds (10 days), ten seeding selected in each Petri dish. The length of seminal root and shoot was measured with the ruler and then, the roots and shoots were separated and placed them individually inside the pocket and placed in an oven at $70^{\circ} \mathrm{C}$ for 48 hours. After drying the shoots and roots, they were weighed per treatment individually.

In this experiment, traits such as the length of seminal root, and seedling, seedling mass, germination rate, germination percentage, seed vigor index I and II were evaluated.

On the tenth day, the count of seminal root, shoot and whole seedling was measured and then the seedling dry weight was determined in the oven for a suitable time. Germination rate was calculated by the Maguire (1982) formula as equation (1):

Germination Rate $(G R)=(\mathrm{a} \backslash 1)+(\mathrm{b}-\mathrm{a} / 2)+(\mathrm{c}-\mathrm{b} \backslash$ $3)+\ldots+(\mathrm{n}-\mathrm{n}-1 / \mathrm{N})$

$M G T=\Sigma(\mathrm{F} . \mathrm{X}) \div \Sigma \mathrm{F}$

In this equation, MGT: mean germination time (day), F: the number of new germinated seeds per day of the counting day $\mathrm{X}$ and $\mathrm{X}$ days of counting. For calculating the seed vigor index, equations (3) and (4) were used (Vashisth \& Nagarajan, 2010).

(3) Vigor index I = germination percentage $\times$ seedling length in $\mathrm{cm}$ (shoot + seminal root) 
(4) Vigor index II = germination percentage $\times$ seedling dry mass in $\mathrm{mg}$ (shoot + seminal root)

Data from the experiment was first processed in Excel spreadsheet software, then statistical analysis of the data was done by MSTAT-C software. Means were compared by Duncan's Multiple range test.

\section{RESULTS AND DISCUSSION}

The results of analysis of variance showed that the application of different concentrations of titanium dioxide nanoparticles had a significant effect on all traits tested (Table 1). Also, different cadmium sulfate contents had a significant effect on other traits. The interaction between titanium dioxide nanoparticles and cadmium sulfate was significant on the rest of the studied traits except for the mean germination time.

The results showed that all concentrations of titanium dioxide increased the seed germination percentage of lentil compared to control which increased $12.4 \%$ relative to the control (Table 2). The application of 300 ppm of titanium dioxide nanoparticles also improved the mean germination time of lentil seeds by $39 \%$ (Table 2). Seed germination rate was from 14.75 seeds per day in the control to 23.9 seeds per day was applied in the treatment of $300 \mathrm{ppm}$ of titanium dioxide nanoparticles which was an increase of $62 \%$ compared to the control. It seems that the nanoparticles have had a positive effect on the rate of water and oxygen exchange from the seed shell to different parts of the seed and ultimately significantly improved seed germination rate.

According to the study conducted by Feizi et al. (2013) on fennel (Foeniculum vulgare L.), it was observed that, treatment of $60 \mathrm{mg} \mathrm{l}^{-1}$ titanium dioxide nanoparticles greatly improved the germination percentage and germination rate. But the treatment of 40 ppm of nonnanoparticles increased the mean germination time by $31.8 \%$. Also, other experimental results on the sage (Salvia officinalis L.) have shown that the concentration of $60 \mathrm{ppm}$ of nanoparticles and non-nanoparticles of titanium dioxide improved germination percentage, and mean germination time compared to control. Furthermore, they declared that the germination rate in the treatment with 60 ppm nanoparticles of titanium dioxide was increased (Feizi et al., 2013). In the investigation of the effect of various concentrations of titanium dioxide nanoparticles on germination traits of silybum (Silybum marianum L.), Agheli et al. (2016) stated that the highest seed germination percentage was observed in the interaction of titanium dioxide nanoparticles treatment at a concentration of $100 \mathrm{ppm}$ and magnetic field intensity of 30 mTesla $(\mathrm{mT})$ and the application of titanium dioxide nanoparticles with a concentration of $50 \mathrm{ppm}$ and a magnetic field intensity of $60 \mathrm{mT}$. These treatments improved the germination percentage by 7.5 and 6.5 times the control treatment.

The effect of different concentrations of titanium dioxide nanoparticles on the growth traits of seedling was different so that the shoot length was increased at lower concentrations, but the application of higher concentrations like $300 \mathrm{ppm}$ resulted in increasing the shoot length. Nanoparticles at the concentration of $100 \mathrm{ppm}$ resulted in a significant increase in shoot length from $2.273 \mathrm{~cm}$ to $2.623 \mathrm{~cm}$. Nevertheless, application of $300 \mathrm{ppm}$ concentration did not have affect its increase (Table 2). The different response of seminal root length was that only 300 ppm concentration caused a significant increase in seminal root length than in the control and increased its value by $26.2 \%$. The concentrations of titanium dioxide nanoparticles (100 and 300 ppm) significantly increased the seedling length compared to the control. The highest seedling length in the $100 \mathrm{ppm}$ nanoparticle treatment was $12.9 \%$ and increased its length from $4.04 \mathrm{~cm}$ to 4.56 cm (Table 2, Figure 2).

Agheli et al. (2016) stated that the maximum seedling length of Silybum marianum was observed in the application of titanium dioxide nanoparticle treatment with a concentration of $100 \mathrm{ppm}$ and a magnetic field intensity of $30 \mathrm{mT}$, and also the application of titanium dioxide nanoparticles with a concentration of $50 \mathrm{ppm}$ and a magnetic field intensity of $60 \mathrm{mT}$. However, application of titanium dioxide nanoparticles had the highest significant effect on seminal root mass of lentil. So that application of concentration of 100 and 300 ppm caused a significant increase of $34 \%$ and $43 \%$ respectively. The lowest seminal root mass was obtained in the control and 200 ppm treatment. Titanium dioxide nanoparticles had no significant effect on shoot and seedling mass (Table 2 ). In the investigation of the effect of titanium dioxide particles on germination of wheat it was observed that, all treatments had significant effect on seminal root mass and the highest root mass was observed in treatments of two and 50 ppm of non-nanoparticles and 100 ppm of titanium dioxide nanoparticles (Feizi, 2012).

The researchers showed that the effect of titanium dioxide nanoparticles on dry biomass was significant at $5 \%$ probability level and reported the highest average (21481.4 $\mathrm{kg} \mathrm{ha}^{-1}$ ) for biological yield for titanium dioxide nanoparticles and the lowest for control (17782.4 $\left.\mathrm{kg} \mathrm{ha}^{-1}\right)$ (Moaveni et al., 2011a).

Seed vigor 1 was significantly affected by titanium dioxide nanoparticles and all concentrations significantly increased it compared to the control and increased its value by about $20 \%$. But seed vigor 2 was significant- 


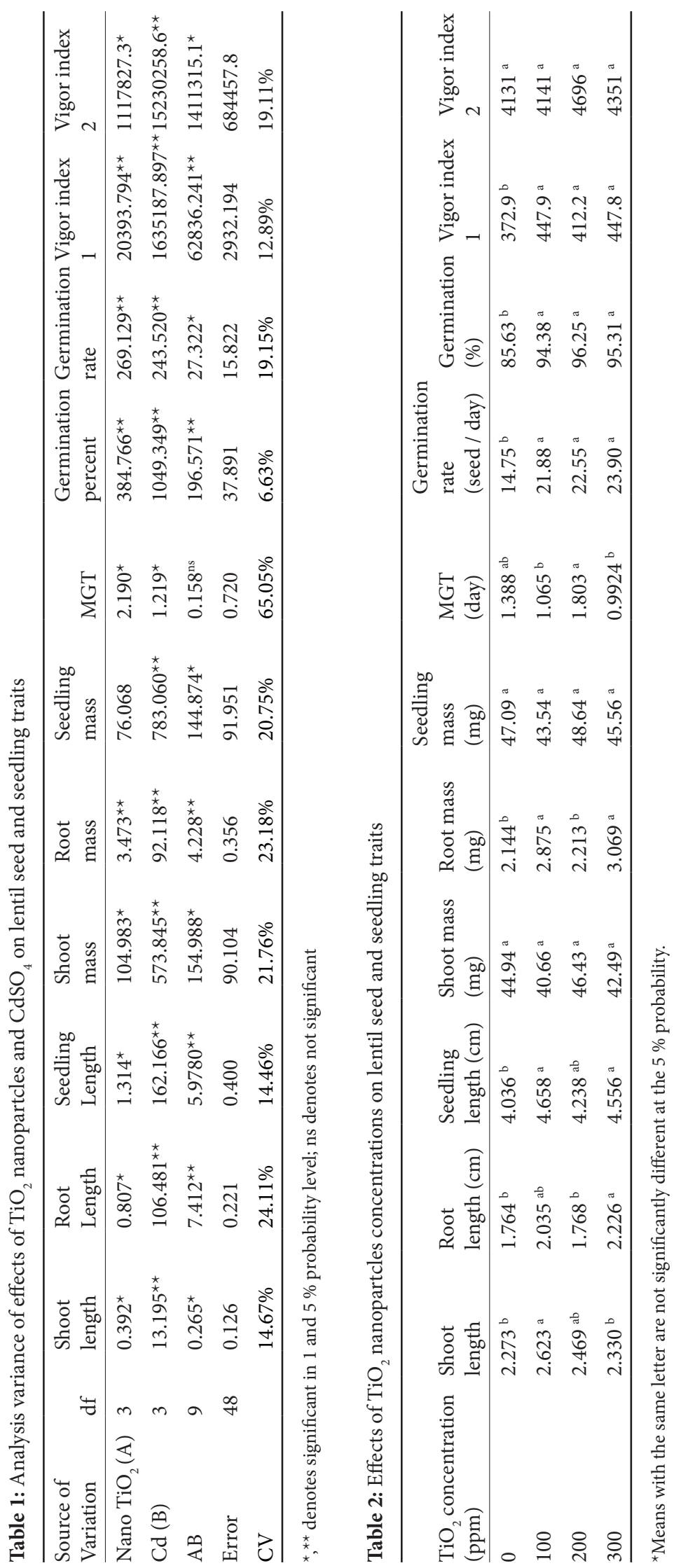




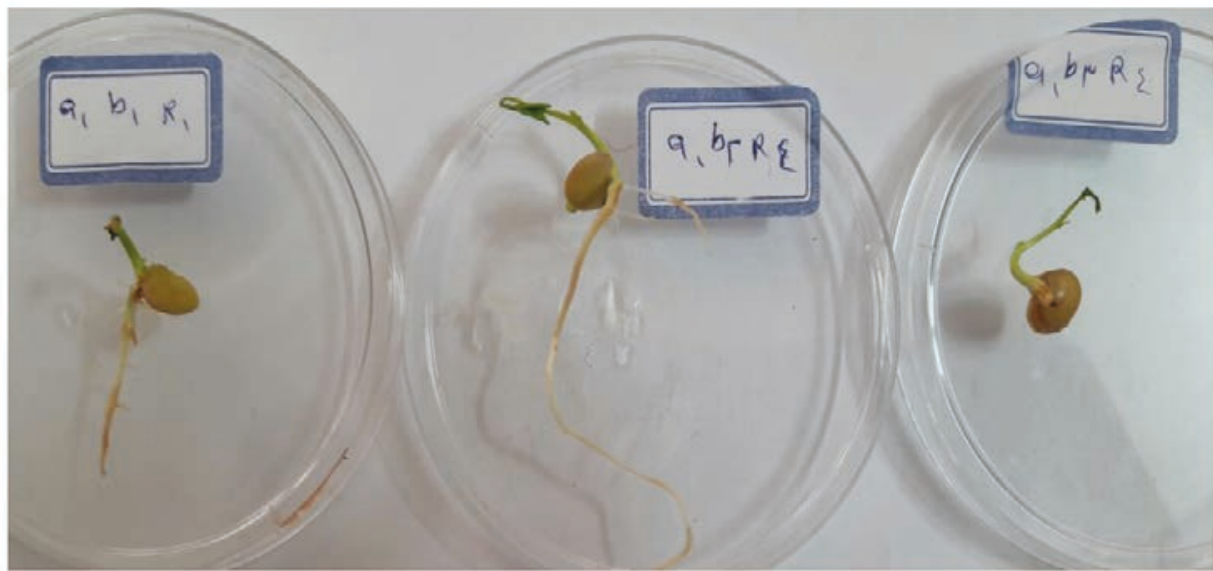

Figure 2: Root and shoot lengths of lentil seedling in $\mathrm{TiO}_{2}$ nanoparticles concentrations

The left Petri dish shows control,

Petri dish in center is 100 ppm $\mathrm{T}_{\mathrm{i}} \mathrm{O}_{2}$ nanoparticles,

The right petri dish is $200 \mathrm{ppm} \mathrm{T}_{\mathrm{i}} \mathrm{O}_{2}$ nanoparticles in the medium.

ly affected by the concentrations of titanium dioxide nanoparticles (Table 2).

The results of exposing seeds to cadmium sulfate showed that, with increasing concentration of cadmium sulfate in growth medium, most traits showed a decreasing trend. The germination percentage of lentil seeds in control and $100 \mathrm{ppm}$ concentration treatments was the highest (97.2 and $99.4 \%$ respectively) and decreased significantly with increasing cadmium sulfate concentrations and, the lowest is obtained at the concentration of $500 \mathrm{ppm}(81.3 \%)$. Also, mean germination time in the control group showed the lowest amount and at the concentration of $500 \mathrm{ppm}$ of cadmium sulfate reaches the highest value (1.667) (Table 3).

According to Shafiq et al. (2008), decrease in germination of seeds could be due to the decomposition of food stored in the seeds as a result of application of cadmium. According to studies on the effect of heavy metals on maize germination, Parmon et al. (2014) opined that heavy metals had a significant effect on maize germination and seed strength. Low levels of metals increase the germination percentage (from $93 \%$ to $98 \%$ in lead nitrate, from $93 \%$ to $97 \%$ in bismuth nitrate and from $94 \%$ to $96 \%$ in cadmium) and seed strength (from 1200 to 1606 in bismuth nitrate and from 1568 to 1592 in lead nitrate), but high levels reduced both parameters. Mahmood et al. (2005) also stated that different levels of copper had no significant effect on maize germination but reduced the early growth of maize.

Application of cadmium sulfate at a concentration of $500 \mathrm{ppm}$ compared to the control reduced the germination rate by $37 \%$. However, the effect of concentrations of 100 and $250 \mathrm{ppm}$ on germination rate was not signifi- cant (Table 3). According to the results, it seems that lentil seeds can tolerate up to $100 \mathrm{ppm}$ of cadmium sulfate in these conditions but higher concentrations cause toxicity for this plant.

The results obtained by Vasilev (2003) about the trait of Hordeum vulgare L. on different levels of cadmium showed that, the maximum effect on reducing growth is related to treatment of $10 \mathrm{mg} \mathrm{l}^{-1}$ of cadmium. The maximum reduction in growth was about 20 percent compared to control treatment.

The application of $100 \mathrm{ppm}$ of cadmium sulfate increased the shoot length compared to the control from $2.876 \mathrm{~cm}$ to 3.264 , and then at concentrations of 250 and $500 \mathrm{ppm}$ significantly reduce it by 17.1 and 59.2 percent (Table 3, Figure 3). But seminal root length showed a significant decrease with increasing concentration of heavy metals. Seminal root length was decreased by 69,92 and $100 \%$, respectively at the concentrations of 100,250 and 500. In other words, the effect of cadmium sulfate toxicity on seminal root was much more than that of the shoot length, since the seminal root was directly exposed to stress, and it had the most contact with this.

The concentration-response phenomenon that is characterized by low-dose stimulation and high-dose inhibition is called as hormesis or hormetic effect. An increased number of studies has described the improved performance of some plant species to Cd exposure, despite $\mathrm{Cd}$ accumulation in their roots and shoots. These results designate that plants have developed protective strategies to neutralize the side-effects from Cd toxicity or, more controversially, mechanisms that employ $\mathrm{Cd}$ as beneficial element (Carvalhoa et al. 2020).

Carvalhoa et al. (2020) reported that carbonic anhy- 


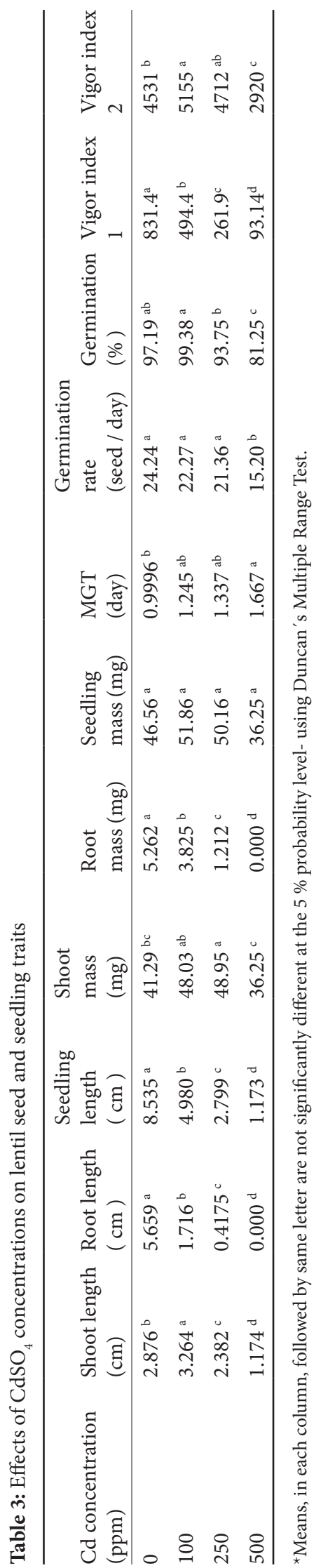
ธี

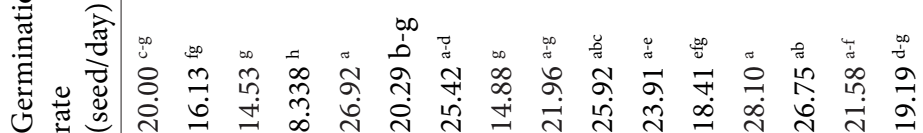

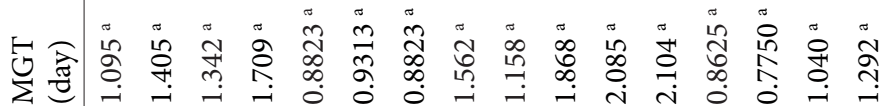
辛

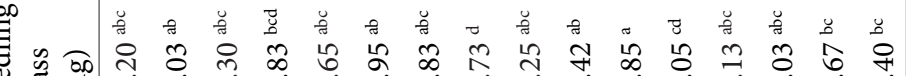

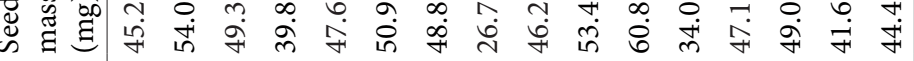

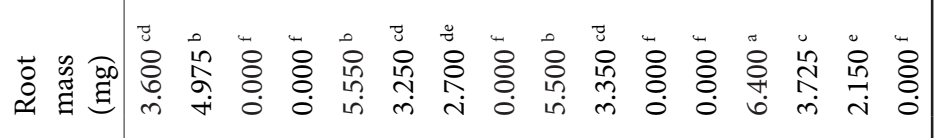

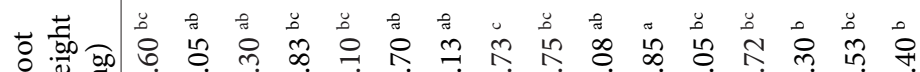

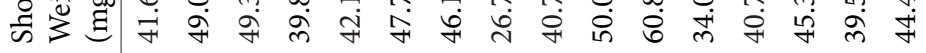

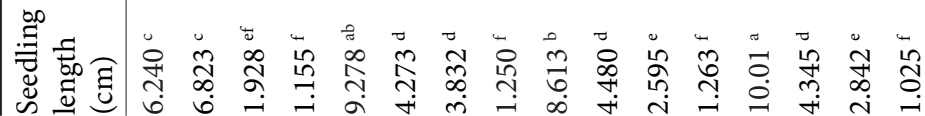

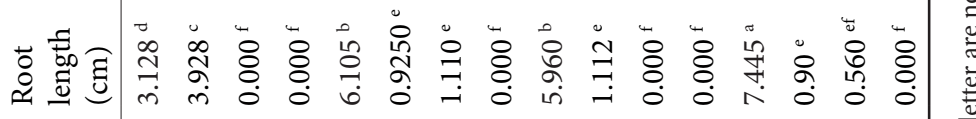

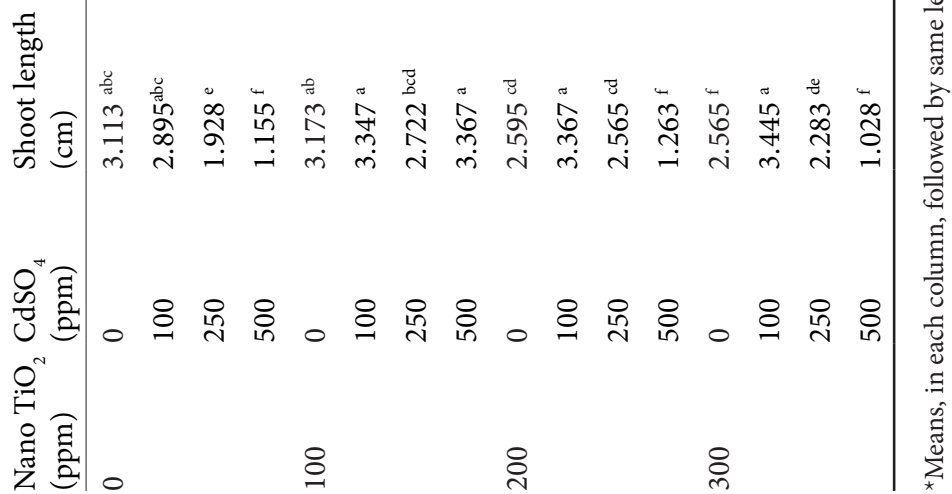


drase activity was also increased in bean plants (Phaseolus vulgaris L.) under exposure to low Cd concentration, despite slight decreases in the amount of this enzyme protein. The results of Ahmadvand et al. (2012) showed that, cadmium treatment reduced the mean of seminal root and shoot length and root to stem (R/S) ratio by $96.83 \%, 29.66 \%$, and $27.52 \%$, respectively compared to control. Similar to seminal root length, the length of the lentil seedlings significantly decreased with increasing cadmium sulfate concentration. The maximum length of seedling was $8.54 \mathrm{~cm}$ in control and less in the treatment of $500 \mathrm{ppm}$ at $1.17 \mathrm{~cm}$ (Equivalent to $86 \%$ of reduction).

Based on experiments conducted on rice plant, the length of aerial organs, plant biomass and water content decreased due to copper pollution. So that at concentrations higher than 0.5, the formation of the root and at a concentration of more than $1.5 \mathrm{mM}$, the formation of the leaf and shoot was stopped (Ahsan et al., 2007).

Also, in a study on Helianthus annuus (L.), the cause of the decrease in seedlings length in the presence of elements such as nickel, copper, cadmium and zinc attributed to the decrease in cellular development. In the existence of heavy metals, plant meristem cells, and lean and endosperm enzymes seems to be reduced, and the cells begin to digest food stores transferred to the primary root and above ground organs in the form of a solution. Therefore, the activity of hydrolytic enzymes is affected when the substrates cannot reach the root and the aerial organs; therefore, it affects the length of the seedling (Houshmandfar \& Moraghebi, 2011).

Also, the highest shoot mass was observed in 250 ppm Cd concentration treatment with $48.95 \mathrm{mg}$ and the lowest in 500 ppm treatment with $36.25 \mathrm{mg}$, which decreased by $12 \%$ compared to control. However, the seminal root mass was more negatively affected by the increased concentration of cadmium sulfate and showed a decreasing trend. The highest seminal root mass was observed in control and lowest in 500 ppm Cd concentration. The total seedling mass was associated with the treatment of $500 \mathrm{ppm}$ of cadmium sulfate which was lower than control by $22 \%$ (Table 3 ). Similar trends were observed in previous studies with respect to cadmium contamination. Moteshare Zadeh et al. (2014) concluded that the highest dry mass of bean shoots (2.25 $\mathrm{g}$ in a pot) was obtained in treatment of $0 \mathrm{ppm}$ of cadmium and the lowest mass ( $1.59 \mathrm{~g}$ in a pot) was obtained at $80 \mathrm{ppm}$ of cadmium. With increasing cadmium concentration, shoot dry mass decreased. With increasing cadmium concentration, root dry mass in the treatment of $80 \mathrm{mg}$ of cadmium was lower than treatment of $40 \mathrm{mg}$. In studying the accumulation of cadmium and lead in shoots of Helianthus annuus, castor, alfalfa and mustard plants in the hydroponic culture, the researchers showed that the biomass of plants decreased with increasing concentration of cadmium and lead (Zhi Xin, et al, 2007).

Increasing the concentration of cadmium sulfate caused a significant decrease in both parts of the seed vigor index and showed the lowest value in both traits (Table 3). According to Parmon et al. (2014), seed strength was also affected by heavy metals. Comparison of mean values indicated that with increasing nitric acid concentration, seed strength was constant and it significantly decreased by reaching the amount of $1000 \mathrm{ppm}$. Increasing the concentration of cadmium caused a sharp decrease in seed vigor.

The production of active radicals and lipid peroxi-

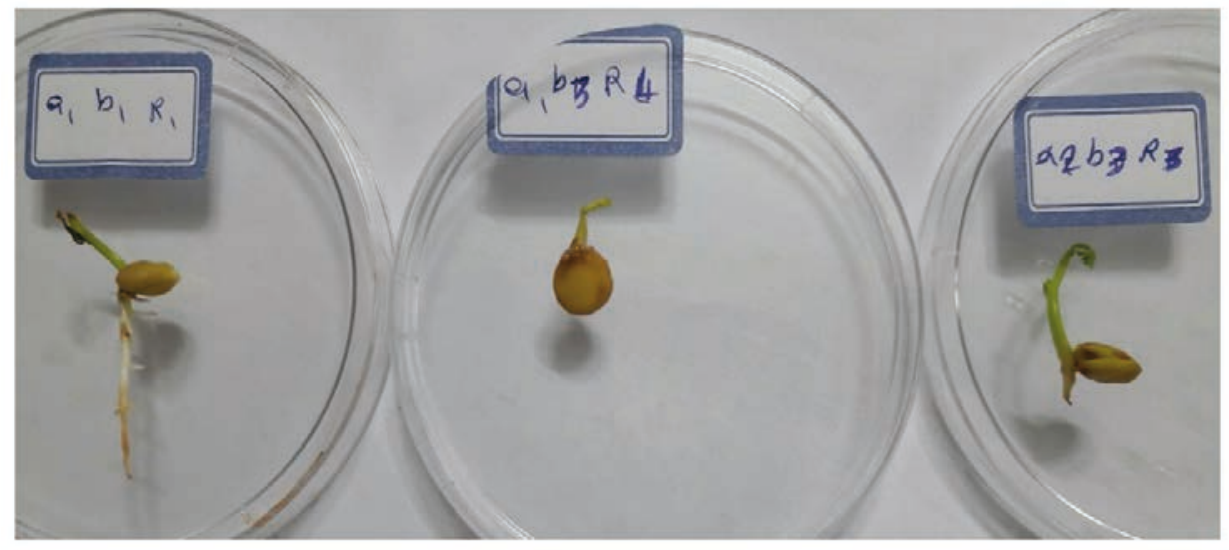

Figure 3: Root and shoot lengths of lentil seedling in $\mathrm{TiO}_{2}$ nanoparticles and cadmium concentrations.

The left Petri dish shows control,

Petri dish in center is 0 ppm $\mathrm{T}_{\mathrm{i}} \mathrm{O}_{2}$ nanoparticles $+250 \mathrm{ppm}$ cadmium

The right Petri dish is $100 \mathrm{ppm} \mathrm{T}_{\mathrm{i}} \mathrm{O}_{2}$ nanoparticles $+250 \mathrm{ppm}$ cadmium in the medium. 
dation, due to oxidative stress, disrupt the function of the cell membrane and eliminate the permeability of its selection, this will increase the leakage of seeded materials and reduce germination and seed vigor. Oxidative stress also changes the activity of antioxidant enzymes (Hussain et al., 2011).

Application of titanium dioxide nanoparticles could significantly reduce the negative effects of cadmium stress and improve lentil germination percentage. In the absence of any nanoparticles, germination percentage of seeds in the treatment of $500 \mathrm{ppm}$ cadmium sulfate was $58.75 \%$. However, using $100 \mathrm{ppm}$ of titanium dioxide nanoparticles (at the same concentration of $500 \mathrm{ppm}$ of cadmium sulfate) germination percentage was $86.25 \%$ which showed an increase of $46.8 \%$ relative to the nonapplication of nanoparticles (Table 4). Such an upward trend was observed in the application of $200 \mathrm{ppm}$ and $300 \mathrm{ppm}$ cadmium concentrations. Under contamination of $200 \mathrm{ppm}$ and $300 \mathrm{ppm}$ cadmium sulphate, titanium dioxide nanoparticles application with a concentration of $200 \%$ increased germination percent by $92.5 \%$. The mutual effect of the application of titanium dioxide nanoparticles and cadmium sulfate on mean germination time was not significant.

The use of titanium dioxide nanoparticles significantly prevent the reduction of the germination rate due to the stress of cadmium sulfate in lentil seeds. In the non-application of nanoparticles, cadmium stress at a concentration of $500 \mathrm{ppm}$ of cadmium sulfate caused a $58 \%$ decrease in germination rate. While in this concentration, the use if $100 \mathrm{ppm}$ nanoparticles of titanium dioxide reduced the germination rate by only 44,16 and $31.7 \%$, respectively (Table 4). Therefore, impregnating our seed with $200 \mathrm{ppm}$ nanoparticles of titanium dioxide before planting can improve the germination rate by $120 \%$ compared to the non-application of nanoparticles under stress conditions of $500 \mathrm{ppm}$ of cadmium sulfate. Therefore, the reduction of the negative effects of heavy metal stress such as cadmium by titanium dioxide nanoparticles, can be considered as a very useful and valuable solution and, this potential is benefited in order to control and reduce such stresses.

The interaction of titanium dioxide nanoparticles and cadmium sulfate on hypocotyl, seminal root and seedling length was significant. The highest shoot length was observed in the treatment of $100 \mathrm{ppm}$ nanoparticles and $500 \mathrm{ppm}$ cadmium sulfate, $200 \mathrm{ppm}$ nanoparticles combined with $100 \mathrm{ppm}$ cadmium sulfate and $300 \mathrm{ppm}$ nanoparticles plus $100 \mathrm{ppm}$ sulfate cadmium. In the conditions of the highest cadmium sulfate stress (500 $\mathrm{ppm}$ ), the use of titanium dioxide nanoparticles generally prevented the effect of heavy metal stress and the shoot length remained unchanged compared to the con- trol $(3.17 \mathrm{~cm}$ in the control and 3.37 in the $500 \mathrm{ppm}$ of cadmium sulfate and $100 \mathrm{ppm}$ nanoparticles of titanium dioxide). Soltani et al. (2014) provided the results of comparison between the interactions showing that the concentration of titanium dioxide nanoparticles was 0.02 $\%$ of foliar application and, the highest grain yield was at the $60 \%$ of shoot and the concentration of titanium dioxide nanoparticles was $0.02 \%$ of foliar application. Also, in flowering stage, it had the lowest grain yield.

\section{CONCLUSION}

The current study results clearly demonstrated the capacity of $\mathrm{TiO}_{2}$ nanoparticles treatments to ameliorate the tolerance to $\mathrm{Cd}$ stress compared to a non-stress condition. The capability of $\mathrm{TiO}_{2}$ nanoparticles treatments to maintain and increase the seed germination percent and seedling characteristics of lentil. The decreased toxicity of $\mathrm{Cd}$ was more likely attributed to the decreased bioavailability of free $\mathrm{Cd}$ ion owing to adsorption and speciation change of $\mathrm{Cd}$ in the presence of $\mathrm{TiO}_{2}$ nanoparticles. The present study demonstrates that $\mathrm{TiO}_{2}$ nanoparticles treatments can be applied to mitigate the negative impact of Cd stress on different pulse crops like lentil in contaminated areas with heavy metals, particularly cadmium. Nevertheless, the interaction between $\mathrm{TiO}_{2}$ nanoparticles and co-existing pollutants in the environment remains uncertain; risk assessment studies have been unconvincing due to the tremendously complicated environmental conditions. Although this study demonstrated the potential of nanoparticles for ameliorating of heavy metal, further exploration and investigation is needed to elucidate and develop these possibilities.

\section{ACKNOWLEDGEMENT}

This work has been supported by the research deputy of Education and Research, University of Torbat Heydarieh, Iran, that the authors hereby acknowledge. The grant number is 11 .

\section{REFERENCES}

Agheli, N., Aliakbarkhani, Z., Behnam, A., Feizi, H. (2016). Stimulation of silybum seed germination and seedling growth by $\mathrm{TiO}_{2}$ nanoparticles and magnetic field. First $\mathrm{Na}$ tional Conference on Medicinal Plants, University of Gonbad Kavus, Iran. (In Persian).

Ahmadvand, S., Bahmani, R. Habibi, D., Forozesh, P. (2012). Study on the effect of cadmium chloride on growth parameters and some physiological traits in bean seedlings. Plant 
Breeding and Agronomy Journal. 8, 165-182 (In Persian with English Abstract).

Ahsan, N., Lee, D.G., Lee, S.H., Kang, K.Y., Lee, J.J., Kim, P.J., Yoon, H.S., and Lee, H.B. (2007). Excess copper induced physiological and proteomic changes in germinating rice seeds. Chemosphere. 67(6), 1182-1193. https://doi. org/10.1016/j.chemosphere.2006.10.075

Carvalhoa M. E.A., Castro, P. RC., Azevedo, R. A. (2020). Hormesis in plants under $\mathrm{Cd}$ exposure: From toxic to beneficial element? Journal of Hazardous Materials. Volume 384 https://doi.org/10.1016/j.jhazmat.2019.121434

Chen, J., Qian, Y., Li, H., Cheng, Y., Zhao, M., (2015). The reduced bioavailability of copper by nano-TiO2 attenuates the toxicity to Microcystis aeruginosa. Environmental Science Pollution Research, 22, 12407-12414. https://doi. org/10.1007/s11356-015-4492-9

Deng, R., Lin, D., Zhu, L., Majumdar, S., White, J.C., GardeaTorresdey, J.L., Xing, B. (2017). Nanoparticle interactions with co-existing contaminants: joint toxicity, bioaccumulation and risk. Nanotoxicology. 11(5), 591-612. https://doi.or $\mathrm{g} / 10.1080 / 17435390.2017 .1343404$

Dolatabadi, A., Sani, B., and Moaveni P. (2015). Impact of nanosized titanium dioxide on agronomical and physiological characteristics of annual medic (Medicago scutellata L.). Cercetări Agronomice în Moldova, 48, 53-61. https://doi. org/10.1515/cerce-2015-0041

Engates, K.E., Shipley, H.J. (2011). Adsorption of Pb, Cd, Cu, $\mathrm{Zn}$, and $\mathrm{Ni}$ to titanium dioxide nanoparticles: effect of particle size, solid concentration, and exhaustion. Environmental Science Pollution Research, 18, 386-395. https://doi. org/10.1007/s11356-010-0382-3

Feizi, H. and Rezvani Moghaddam, P. (2011). Influence of magnetic field and silver nanoparticles in comparison to macro and micro nutrient fertilizers on growth, yield and silage quality of maize. Journal of Water and Soil, 24, 1062-1072. (In Persian with English Abstract).

Feizi, H. (2012). The role of metallic nanoparticles $\left(\mathrm{TiO}_{2}, \mathrm{Fe}_{2} \mathrm{O}_{3}\right)$ and magnetic field on germination, nutrient absorption, growth and quantitative and qualitative characteristics of wheat. PhD. Thesis. Ferdowsi University of Mashhad, Iran. (In Persian with English Abstract).

Feizi, H., Kamali, M., Jafari, L. \& Rezvani Moghaddam, P. (2013). Phytotoxicity and stimulatory impacts of nanosized and bulk titanium dioxide on fennel (Foeniculum vulgare Mill). Chemosphere, 91, 506-511. https://doi.org/10.1016/j. chemosphere.2012.12.012

Houshmandfar, A., and Moraghebi, F. (2011). Effect of mixed cadmium, copper, nickel and zinc on seed germination and seedling growth of safflower. African Journal of Agricultural Research, 6(5), 1182-1187.

Hussain, S.S., Ali, M., Ahmad, M., and Siddique, K.H.M. (2011). Polyamines: natural and engineered abiotic and biotic stress tolerance in plants. Biotechnology Advances, 29(3), 300-311. https://doi.org/10.1016/j.biotechadv.2011.01.003

ISTA. (2009). ISTA Rules. International Seed Testing Association. Zurich, Switzerland. $47 \mathrm{pp}$.

Mahmood, S., Hussain, A., Zaeed, Z., and Athar, M. (2005). Germination and seedling growth of corn (Zea mays L.) under varying levels of copper and zinc. International Journal of Environmental Science Technology, 2(3), 269-274. https://doi.org/10.1007/BF03325886

Maguire, I. D. (1982). Speed of germination - Aid in selection and evaluation for seedling emergence and vigor. Crop Science, 22, 177-176. https://doi.org/10.2135/cropsci1962.001 $1183 X 000200020033 x$

Miao, W., Zhu, B., Xiao, X., Li, Y., Dirbaba, N.B., Zhou, B., Wu, H. (2015). Effects of titanium dioxide nanoparticles on lead bioconcentration and toxicity on thyroid endocrine system and neuronal development in zebrafish larvae. Aquatic Toxicology, 161, 117-26. https://doi.org/10.1016/j.aquatox.2015.02.002

Moaveni, P., Talebi, R., Farahani, H.A. and Maroufi, K. (2011). Effect of $\mathrm{TiO}_{2}$ nanoparticles spraying on barley (Hordem vulgare L.) under field condition. Advances Environmental Biology, 5(7), 1663-1667.

Motesharezade, B., Aghaee, L., Savaghebi, G. (2014). Influence of $\mathrm{Cd}$ and $\mathrm{Pb}$ application on their absorption and growth of two bean cultivars. Environmental Stress in Crop Science, 7, 257-271. (In Persian with English Abstract).

Pais, I. (1983). The biological importance of titanium. Journal of Plant Nutrition, 6, 3-131. https://doi. org/10.1080/01904168309363075

Parmoon, G., Ebadi, A., Ghaviazm A., and Miri, M. (2013). Effect of seed priming on germination and seedling growth of Chamomile under salinity. EJCP, 6(3), 145-164. (In Persian with English Abstract).

Parmoon, G. Ebadi, E. Ghahremani, M. Moosavi, S.A. (2014). Influence of heavy metal on seed germination and vigor of maize in control condition. Journal of Seed Research, 4, 4051. (In Persian with English Abstract).

Shafiq M., Iqbal, M.Z. and Athar M. (2008). Effect of lead and cadmium on germination and seedling growth of Leucaena leucocephala. Journal of Science Environmental Management, 12(2), 61- 66.

Soltani, M., Moaveni, P. Noori H. (2014). Investigation of foliar application effect of $\mathrm{TiO} 2$ nanoparticles on yield and yield component of lentil. Iranian Journal Plant Ecophysiology Research, 9, 78-88. (In Persian with English Abstract).

Tan, C., Wang, W.X., (2014). Modification of metal bioaccumulation and toxicity in Daphnia magna by titanium dioxide nanoparticles. Environmental Pollution, 186, 36-42. https:// doi.org/10.1016/j.envpol.2013.11.015

Vashisth, A., and Nagarajan, S. (2010). Effect on germination and early growth characteristics in sunflower (Helianthus annuus) seed exposed to static magnetic field. Journal of Plant Physiology, 167, 149-156.

Vassilev, A. (2003). Barley seedlings as bio-indicators for water contamination by cadmium. Journal of Environmental Protection and Ecology, 4(2), 354-360. https://doi.org/10.1016/j. jplph.2009.08.011

Zhi-Xin, N., Li-na, S., Tie-heng, S., Yu-shuang L., and Hong, W. (2007). Evaluation of phytoextracting cadmium and lead by sunflower, ricinus, alfalfa and mustard in hydroponic culture. Environmental Sciences, 19, 961-967. https://doi. org/10.1016/S1001-0742(07)60158-2 